may physically obliterate the lumen (Meikle, 1955. Fig. 3). The cysts may induce a volvulus; the cysts may exert extrinsic pressure on other loops of bowel. They may give rise to inflammatory reactions and adhesions (Jones \& Cole, 1967).

2. Intussusception. A submucosal cyst may act as the apex of an intussusceptum.

3. Pneumoperitoneum. In rare cases, tension pneumoperitoneum may occur.

4. Interposition of the bowel between the liver and the diaphragm (Case 4, Dhall et al., 1968).

\section{Discussion}

$\mathrm{PCI}$ is a rare condition the diagnosis of which can usually be made with certainty if the possibility is considered. The disease may be discovered as an incidental finding on plain films of the chest and abdomen. The chest X-ray, which may show evidence of chronic respiratory disease can demonstrate interposition or a pneumoperitoneum with cysts and a 'foamy' appearance below the diaphragm. PCI should always be considered when a pneumoperitoneum occurs without other clinical evidence of perforation of a hollow viscus (Somerville, 1951). These appearances may also be found on the plain film of the abdomen and in addition cysts may be seen along the line of the bowel, particularly the colon. The plain film appearances are unmistakable once it is realized that the gas is not intraluminal.

A barium enema will confirm the findings in the large bowel. The differential diagnosis includes faeces, polyposis, the pseudo-polypoidal form of ulcerative colitis, thumb-printing in mesenteric vascular disease and carcinoma but these conditions will not give rise to translucent filling defects.

The diagnosis is less easy if the disease is confined to the small bowel and will be best demonstrated in the follow-through examination. The preceding meal will also reveal any peptic ulceration or stenosis.

Once the diagnosis is made and alimentary tract malignancy has been excluded there is no specific treatment and spontaneous remission can be expected if complications do not supervene.

\section{References}

Colquhoun, J. (1965) Intramural gas in hollow viscera. Clinical Radiology, 16, 71.

Dendy Moore, H. (1968) Diagnosis and natural history of gas cysts of the colon. British Medical Journal, 2, 536.

Dhall, D.P., Mahaffy, R.G. \& Matheson, N.A. (1968) Intestinal pneumatosis treated by pyloroplasty. Journal of the Royal College of Surgeons of Edinburgh, 13, 226.

JoNES, A.W. \& COLE, F.M. (1967) Intestinal obstruction due to pneumatosis intestinalis. Postgraduate Medical Journal, 43, 680 .

KenNeY, J.G. (1963) Pneumatosis intestinalis. Clinical Radiology, 14, 70.

Koss, L.G. (1952) Abdominal gas cysts (Pneumatosis cystoides intestinorum hominis). Archives of Pathology, 53, 523.

MeIKLE, G. (1965) A case of pneumatosis coli. Journal of the Royal College of Surgeons of Edinburgh, 11, 65.

Somerville, P. (1951) Gas cysts of the intestine with pneumoperitoneum. Lancet, ii, 1160.

\title{
Hypercalcaemia in thyrotoxicosis with and without hyperparathyroidism
}

\author{
ANTHONY J. RICHARDS \\ M.B., M.R.C.P. \\ Medical Registrar, Westminster Hospital, London, S.W.1
}

\section{Summary}

Two cases of thyrotoxicosis with hypercalcaemia are reported. The hypercalcaemia in one of the patients was a manifestation of hyperthyroidism and in the other was due to co-existent hyperparathyroidism.

The literature is reviewed and the effect of thyroid hormone on calcium metabolism is discussed. Routine plasma calcium estimations should be performed in all cases of thyrotoxicosis.

\section{Introduction}

Hypercalcaemia in thyroid disease occurs infrequently. Significant hypercalcaemia in thyrotoxicosis may occur with or without accompanying hyperparathyroidism, and an example of each is reported.

\section{Method}

Plasma calcium was measured by the EDTA/ calcon method (Bowden \& Patston, 1963) and all values were corrected for total serum protein, as suggested by Dent (1962). The normal range of plasma calcium in this laboratory is $8.4-10.5 \mathrm{mg}$ / $100 \mathrm{ml}$.

Case 1: Thyrotoxic hypercalcaemia

A 25-year-old unmarried woman was admitted to Westminster Hospital in February 1969. She gave a 
history of nausea and vomiting, weight loss and abdominal pain since November, 1968. Two months before admission, she developed amenorrhoea, but denied pregnancy. Her parents had noticed her eyes becoming prominent and the development of a goitre.

She was seen in the Out Patient Department of another hospital in January, 1969, where a barium meal was carried out, which was normal. No tests of thyroid function were performed, and she did not re-attend for follow-up.

There was no family or personal history of any serious past illnesses or thyroid disorder.

On examination she was thin, pale, with a stare, lid-lag and a fine tremor of the hands. She was not pyrexial, but had a sinus tachycardia of $128 / \mathrm{min}$. The thyroid gland was diffusely enlarged, and there was a bruit over the more prominent right lateral lobe. There was no lymphadenopathy.

Investigations: $\mathrm{Hb} 82 \%$; W.B.C. $5200 \mathrm{c} / \mathrm{mm}$ with a normal differential; ESR $22 \mathrm{~mm} / \mathrm{hr}$. (Wintrobe); urine specific gravity 1005 . No proteinuria or glycosuria. Pregnancy test negative. Radio-active ${ }^{132} \mathrm{I}$ uptake $100 \%$; plasma thyroxine $\left(T_{4}\right) 27 \cdot 4 \mu \mathrm{g} / 100 \mathrm{ml}$ (normal 4.0-11.0); thyroglobulin tanned cells test was positive, but the complement fixation test (CFT) was negative. Long acting thyroid stimulator (LATS) was not detected on assay. Plasma calcium was 12.7 $\mathrm{mg} / 100 \mathrm{ml}$; plasma phosphate $2.7 \mathrm{mg} / 100 \mathrm{ml}$, and the serum albumin $2 \cdot 3 \mathrm{~g} / 100 \mathrm{ml}$ (normal $3 \cdot 4-4 \cdot 6$ ). Further determinations confirmed the hypercalcaemia (Fig. 1). Urinary calcium was high, $426 \mathrm{mg} /$ $24 \mathrm{hr}$ (normal up to $300 \mathrm{mg} / 24 \mathrm{hr}$ ). Plasma electrolytes were normal on admission with a slightly raised plasma urea of $48 \mathrm{mg} / 100 \mathrm{ml}$. The plasma potassium fell to $2.8 \mathrm{mEq} / \mathrm{l}$, but this and the plasma urea became normal when normocalcaemia was established.

$\mathrm{X}$-rays of chest, thoracic inlet, abdomen, skull and hands were normal. An ECG confirmed sinus tachycardia with QT interval at the lower limit of normal.

Oral hydrocortisone (40 mg 8-hourly) produced a fall in plasma calcium from $12.0 \mathrm{mg} / 100 \mathrm{ml}$ to 9.7 $\mathrm{mg} / 100 \mathrm{ml}$ after 4 days. When hydrocortisone was stopped, the plasma calcium rose to its former high value and nausea and vomiting, which had ceased in the normocalcaemic phase, returned.

She was then started on propranolol $40 \mathrm{mg} \mathrm{6-}$ hourly, and carbimazole $20 \mathrm{mg} 8$-hourly. The plasma calcium fell to normal after 2 weeks, and has remained so since discharge from hospital. She is now clinically euthyroid and symptom-free, taking carbimazole, 5 mg 8-hourly.

Alkaline phosphatase was slightly raised on admission to hospital (19 K.A. units/100 ml), but as an out-patient rose to $28 \mathrm{~K}$.A. units $/ 100 \mathrm{ml}$ with a normal plasma calcium. It has subsequently fallen to normal, and she has not been given supplementary calcium or Vitamin D.

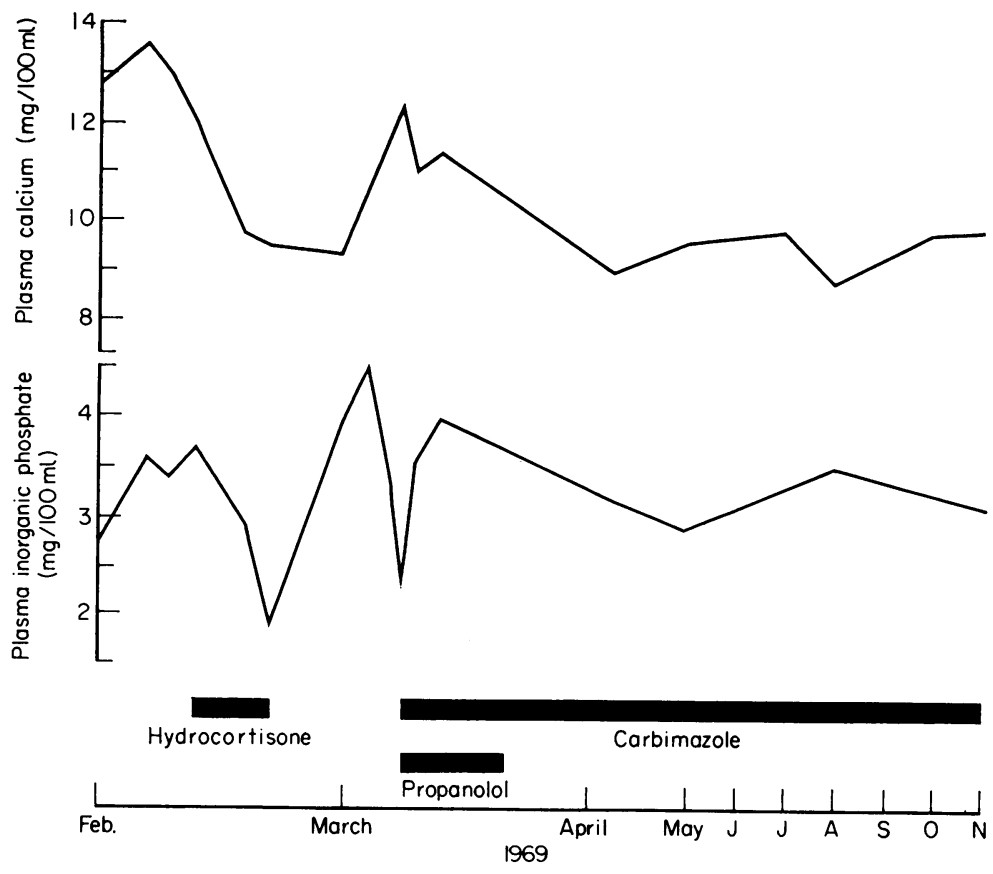

FIG. 1. Hypercalcaemia suppressed initially by hydrocortisone and later by treatment of thyrotoxicosis. 


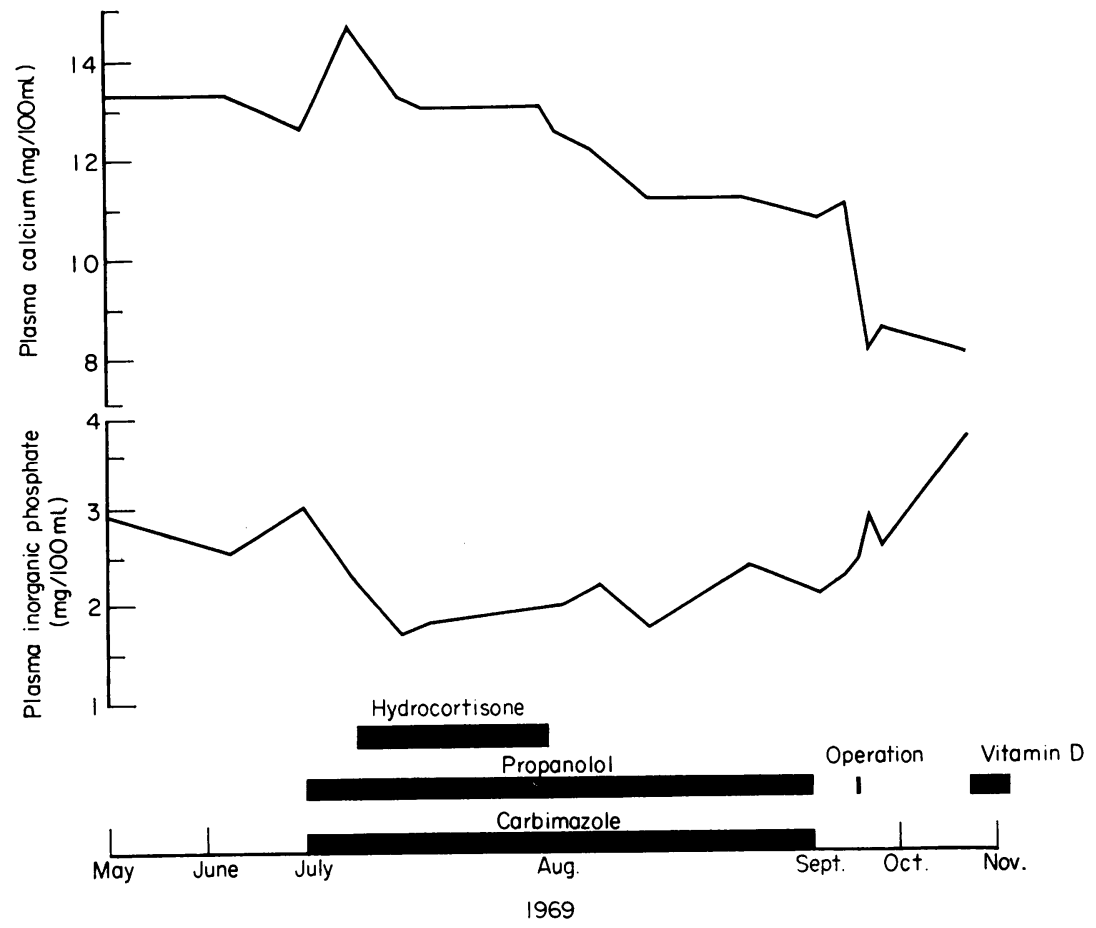

Fig. 2. No suppression of hypercalcaemia until after removal of a parathyroid adenoma.

\section{Case 2: Thyrotoxicosis with hyperparathyroidism}

A 63-year-old married woman first attended Westminster Hospital in May 1969, complaining of weakness, loss of appetite and weight loss for 1 year. She was also constipated, suffered intermittent abdominal pain, and had polyuria for 3 months.

The plasma calcium was found to be $13.3 \mathrm{mg} /$ $100 \mathrm{ml}$ with a normal plasma phosphate and an alkaline phosphatase of 13 K.A. units $/ 100 \mathrm{ml}$ and she was admitted for further investigation in June 1969.

In the family history, two sisters had undergone partial thyroidectomy elsewhere for thyrotoxicosis, one in 1956, the other in 1968. Histology of both glands showed lymphadenoid infiltration.

On examination she was thin, anxious, with tremor of the hands and a slight degree of lid-lag. The thyroid gland was enlarged and nodular and the trachea was displaced to the right. The pulse was $110 / \mathrm{min}$ and the reflexes were brisk. She was apyrexial.

There was generalized abdominal tenderness, and one observer thought a mass to be palpable in the left upper quadrant. There was no lymphadenopathy.

Investigations: $\mathrm{Hb} 12.0 \mathrm{gm} / 100 \mathrm{ml}$; WBC 6300 $\mathrm{c} / \mathrm{mm}$; ESR $9 \mathrm{~mm} / \mathrm{hr}$. (Wintrobe). No albuminuria or glycosuria. ${ }^{132} \mathrm{I}$ uptake $100 \%$; plasma $\mathrm{T}_{4} 17 \mu \mathrm{g} /$ $100 \mathrm{ml}$; Thyroglobulin tanned cell and CFT negative. LATS assay not done. ${ }^{131}$ I scan showed increased uptake over the left lobe of the thyroid. Repeat ${ }^{132} \mathrm{I}$ uptake, after triiodothyronine, $40 \mu \mathrm{g}$, 8-hourly for 6 days, was still $100 \%$. Plasma calcium was raised (Fig. 2) and the serum albumin was $3 \cdot 2$ $\mathrm{g} / 100 \mathrm{ml}$ and the globulin $3.2 \mathrm{~g} / 100 \mathrm{ml}$. Slit-lamp examination revealed calcification at the corneal limbi.

Plasma electrolytes and urea were normal on admission, but she developed moderate hypokalaemia, although the plasma potassium never fell below $3.0 \mathrm{mEq} / 1$.

Chest X-ray confirmed tracheal deviation to the right and the heart was enlarged in its transverse diameter. Skull X-ray showed a decalcified sella, and X-ray of the hands showed osteoporosis. Barium meal and enema and pancreatic scan with ${ }^{75}$ Se were normal. An ECG was normal.

Oral hydrocortisone (40 mg 8-hourly) did not produce normocalcaemia after a 13-day course (Fig. 2). Treatment was then started with oral propranolol, carbimazole and potassium, and her appetite improved and she gained weight. Her pulse fell to 56/ min. She was discharged in August 1969, taking carbimazole, $10 \mathrm{mg}$ 6-hourly, and propranolol, 40 mg 12-hourly. 
In view of the almost certain fact that she had coexisting hyperthyroidism and hyperparathyroidism, Lugol's iodine was given as an out-patient and she was re-admitted for exploratory surgery.

At operation on 10 September, a nodule, $2.5 \mathrm{~cm}$ in diameter, was found in the sternal notch. This proved on histology, to be a parathyroid adenoma. Other parathyroid tissue was searched for, but not found. The thyroid gland was enlarged and nodular and the left lobe was larger than the right. Sub-total thyroidectomy was performed and histology showed a small foetal adenoma with some hyperplasia.

The postoperative plasma calcium levels were normal. She was discharged feeling well and not on any medication. In October, it was noticed that her voice was hoarse, and she complained of 'pins and needles' in the fingers. A plasma calcium was $8.1 \mathrm{mg} /$ $100 \mathrm{ml}$, alkaline phosphatase 22 K.A. units $/ 100 \mathrm{ml}$. She was started on oral Vitamin-D, 3000 units daily and is at present symptom-free.

\section{Discussion}

\section{Thyrotoxic hypercalcaemia}

This is becoming increasingly recognized, but up to 1963 , only thirty-one definite cases had been documented, according to Torsti \& Lamberg (1963). However, Baxter \& Bondy (1966), on reviewing the records of 302 hyperthyroid patients, found nineteen to have hypercalcaemia, in only two of these due to associated hyperparathyroidism. Adams et al. (1967) have shown that the mean serum calcium of hyperthyroid patients tends to be higher than that of normal subjects, matched for sex and age; and the serum ionized calcium is also higher in hyperthyroid patients (Frizel, Malleson \& Marks, 1967), possibly because of a tendency to hypoalbuminaemia (Man, Gildea \& Peters, 1940).

The first authentic report of thyrotoxic hypercalcaemia was by Wijnbladh (1937), and similar cases to to this present one have been reported (Stanley \& Fazekas, 1949; Guyer, 1965; Harris-Jones, Nakadar \& Wells, 1967). The height of plasma (or serum) calcium can be extremely variable, and bears no relation to the severity of the thyrotoxicosis (Bortz et al., 1961; Baxter \& Bondy, 1966). In the second case of Rose \& Boles (1953), the serum calcium ranged from 11.2 to $19.9 \mathrm{mg} / 100 \mathrm{ml}$, and gradually fell following subtotal thyroidectomy. An interesting feature of that case is that recurrence of thyrotoxicosis did not then provoke a rise in the serum calcium.

In thyrotoxic hypercalcaemia, the symptoms of hypercalcaemia, namely nausea, vomiting, abdominal pain and constipation, are often predominant and may mask the accompanying thyrotoxicosis. Despite the hypercalcaemia and hypercalcuria, the literature lacks reference to the occurrence of renal calculi in these patients, although nephrocalcinosis and renal tubular acidosis have been described (Epstein, Freedman \& Levitin, 1958; Huth, Maycock and Kerr, 1959). The plasma urea is invariably raised due to dehydration, and with adequate hydration usually falls to normal, even though serum calcium remains elevated (Pribek \& Meade, 1957). The low plasma potassium that is invariably found, as in case 1 , is thought to be due to excessive renal loss of potassium, and this also occurs in hyperparathyroidism (Sanderson, 1967). A recent case report of thyrotoxic hypercalcaemia (Harper \& Osborne Hughes, 1970) had a persistently raised serum alanine amino-transferase and gastro-intestinal bleeding; other liver function studies were normal. Liver function tests were not carried out on the present case.

To differentate hypercalcaemia due to thyrotoxicosis from that due to hyperparathyroidism, the cortisone suppression test (Dent, 1956), now modified by the substitution of hydrocortisone (Dent \& Watson, 1966), may help. Cases 1 and 2 demonstrate its usefulness. In case 1 , normocalcaemia was attained 4 days after starting hydrocortisone, while in case 2 , the plasma calcium was still above normal after 13 days. Prednisone has also been shown to cause a fall in serum calcium when this is due to thyrotoxicosis (Bortz et al., 1961; Sataline, Powell \& Hamwi, 1962; Harper \& Osborne Hughes, 1970). Rarely, the raised serum calcium does not respond to steroids, and may only fall when the hyperthyroidism is controlled (David, Verner \& Engel, 1962). Very occasionally, the hypercalcaemia of hyperparathyroidism may be suppressed by steroids (Gwinup \& Sayle, 1961 ; Dent, 1962; Hodges \& Waterhouse, 1967; Garcia \& Yendt, 1968).

The role of thyroid hormone in calcium metabolism has prompted much discussion. Excretion of calcium in thyrotoxic subjects is high, due to a direct catabolic effect of thyroid hormone on bone (Aub et al., 1929). Puppel et al. (1945) and Cook, Nassim \& Collins (1959), found excessive loss of calcium via faecal and urinary routes, as compared with hyperparathyroidism, in which increased excretion of calcium occurs almost exclusively through the urine. Thyroid hormone has also been shown to have an elevating effect on serum calcium levels in the absence of the parathyroid glands (Aub et al., 1932; Cope \& Donaldson, 1937). The fact that the parathyroid glands are thought to play no part in thyrotoxic hypercalcaemia is supported by the tendency to hyperphosphataemia (Cook et al., 1959) and the increased tubular re-absorption of phosphate (Adams et al., 1967) which becomes normal when hyperthyroidism is treated (Parsons \& Anderson, 1964). Harrison, Harden \& Alexander (1964) demonstrated 
that exogeneous parathyroid hormone produced a greater rise in serum calcium in hyperthyroid subjects than in normal controls. The interpretation is that endogenous parathyroid secretion is already suppressed by the increased calcium load imposed by the hyperthyroid state. The handling of an intravenous calcium load was studied in a hypercalcaemic, hyperthyroid patient and this led to a decrease of $79 \%$ in the excretion of phosphorus indicating that hyperparathyroidism was unlikely to be implicated (Koenig, Scholz \& Salassa, 1957).

Bone lesions may occur in hyperthyroid subjects with or without hypercalcaemia. There is increased bone formation as well as increased bone destruction (Krane et al., 1956) and these changes may occur in the absence of radiographic evidence of bone disease (Adams et al., 1967). The bones involved are spine, ribs and pelvis, and less frequently skull, hands and long bones (Werner, 1962). The bone lesions have been reported as those of osteitis fibrosa cystica (Von Recklinghausen, 1891; Follis, 1953). Osteoporosis (Cook et al., 1959), and osteomalacia have also been described (Follis, 1953), although the more recent studies of Adams et al. (1967) do not support the suggestion that osteomalacia is a feature of hyperthyroidism. Thyrotoxic bone disease is not seen more frequently because the underlying disorder in the majority of cases is corrected before the demineralization proceeds to a clinically demonstrable level (Kleeman, Tuttle \& Bassett, 1958). Case 1 presumably had mild osteitis fibrosa as the phosphatase was raised before treatment and rose further after treatment, before eventually settling to normal, a phenomenon which has been noted previously by Dent \& Harper (1958). Increased retention of an intravenous calcium load is seen in hyperthyroid subjects as compared with normal controls (Lim, Jacob \& Khoo, 1969) and these authors postulate that this may be due to an increased calcitonin production. Other workers, from their studies on induced hypercalcaemia in hyperthyroid subjects, have debated a possible functional deficiency of calcitonin (Klotz et al., 1968). Recently a case of thyrotoxic hypercalcaemia was treated with intravenous porcine calcitonin with a temporary fall in serum calcium (Buckle, Mason \& Middleton, 1969).

It is likely that in thyrotoxic hypercalcaemia the level of calcitonin is raised-induced hypercalcaemia causes a rise in plasma calcitonin in normal subjects (Gudmundsson et al., 1969), but the increase is still insufficient to counteract the catabolic effect of thyroxine on bone. Alternatively, thyroxine may increase peripheral utilization of calcitonin to the point of causing relative deficiency (Lancet, 1967). Assays of calcitonin in hyperthyroid subjects with and without hypercalcaemia obviously need to be carried out.

\section{Thyrotoxicosis with hyperparathyroidism}

This is a rare association. Since the first clearly documented case by Noble \& Borg (1936), only thirty other cases, including the present one, are known to my knowledge to have been described or referred to (Table 1), and this includes eight cases,

TABLE 1. Thyrotoxicosis with hyperparathyroidism

\begin{tabular}{|c|c|c|c|}
\hline No. & Author & Sex & Age \\
\hline 1. & Noble \& Borg (1936) & $\mathrm{F}$ & 33 \\
\hline 2. & Miller \& Evans (1942) & $\mathrm{F}$ & 51 \\
\hline 3. & Koenig, Scholz \& Salassa (1957) & F & 60 \\
\hline 4. & Hubble (1958) & $\mathrm{F}$ & 56 \\
\hline 5. & Randall \& Keating (1958) & $\mathrm{F}$ & 70 \\
\hline 6. & Frame \& Durham (1959) & M & 63 \\
\hline 7. & Gassmann \& Haas (1960) & $F$ & 50 \\
\hline 8. $\}$ & Bortz et al (1961) & $\mathrm{F}$ & 68 \\
\hline 9. $\}$ & Bortz et al. (1961) & $\mathbf{M}$ & 65 \\
\hline 10. & Gadeholt (1961) & $\mathrm{F}$ & 37 \\
\hline 11. & Jackson et al. (1961) & $\mathbf{F}$ & 37 \\
\hline 12. & Ellenberg et al. (1962) & - & - \\
\hline 13. $\}$ & Gordan et al. (1962) & - & - \\
\hline $\begin{array}{l}14 . \\
15 .\end{array}$ & C Givant et ai. (1) & $\bar{F}$ & $\overline{55}$ \\
\hline 15. & & $\mathrm{F}$ & 32 \\
\hline 17. & Hellstrom \& Ivemark (1962) & $\mathbf{M}$ & 59 \\
\hline 18. & & - & - \\
\hline 19. & Torsti \& Lamberg (1963) & $\begin{array}{l}\text { M } \\
\mathbf{F}\end{array}$ & 56 \\
\hline 21. & Bryant, Wulsin \& Altemeier (1964) & $\mathrm{F}$ & $\begin{array}{l}01 \\
44\end{array}$ \\
\hline 22. & Fields \& Burkett (1964) & M & 48 \\
\hline 23. & Austoni (1965) & $\mathbf{M}$ & 22 \\
\hline & Breuer \& McPherson (1966) & $\mathbf{M}$ & 42 \\
\hline 25. & Ahuja \& Chopra (1968) & $\mathrm{F}$ & 38 \\
\hline 26. ? & & - & - \\
\hline 27. & & - & - \\
\hline 28. & Davies, Dent \& Watson (1968) & - & - \\
\hline 29. & & - & - \\
\hline 30. & & - & - \\
\hline 31. & Present case & $\mathrm{F}$ & 63 \\
\hline
\end{tabular}

full details of which are not known. (Gordan et al., 1962; Ellenberg et al., 1962; Davies, Dent \& Watson, 1968). Earlier case reports have been lacking in either definite histological evidence of hyperparathyroidism or clinical evidence of thyrotoxicosis and are not included in this list (Wendel, 1930; Ball, 1930; Meyer-Borstel, 1930; Cooley, 1931; Ballin \& Morse, 1931; Bergstrand, 1931; Hellstrom, 1932, 1954).

It is difficult to see any causal relationship between hyperthyroidism and hyperparathyroidism. There appears to be a preponderance of females in cases where the sex is known, and the thyroid is usually nodular. Many diseases are now known to be associated with primary hyperparathyroidism (Davies et al., 1968) and it is probably fortuitous that thyrotoxicosis happens to be one of them.

In some of the cases, thyrotoxicosis was detected first, in others hyperparathyroidism, while in a few hyperparathyroidism was discovered incidentally at operation (Randall \& Keating, 1958), or a para- 
thyroid adenoma was found embedded in the goitre (Frame \& Durham, 1959). In the present case, hyperparathyroidism was thought likely in view of the presenting symptoms and was confirmed by the finding of corneal calcification, and the failure to respond to a hydrocortisone suppression test. Hand tremor, brisk reflexes, and a nodular goitre, as well as a family history of thyroid trouble suggested co-existing thyrotoxicosis, and this was confirmed by radio-active iodine uptake. Hypophosphataemia (below $2 \cdot 3 \mathrm{mg} / 100 \mathrm{ml}$ ) in the present case was another pointer towards hyperparathyroidism, but a normal plasma phosphate should not deter one from making this diagnosis as normophosphataemia was recorded in $41 \%$ of cases of hyperparathyroidism by Keating (1961). Renal tubular reabsorption of phosphate is usually low in hyperparathyroidism and this was shown in the two patients of Bortz et al. (1961), although this is not always the case and may be normal (Ahuja \& Chopra, 1968).

Whenever a raised plasma calcium is found in a case of thyrotoxicosis, hyperparathyroidism must be the first diagnosis to consider and exclude, rather than attributing the raised calcium level solely to the thyrotoxicosis. Surgical exploration is obligatory if the plasma calcium remains high after treating the thyrotoxicosis. By adopting this approach, serious renal and bone disease may be avoided.

\section{Acknowledgments}

I should like to thank Dr P. R. Fleming and Dr R. D. Tonkin, Westminster Hospital for permission to publish details of cases 1 and 2 respectively, and the Department of Chemical Pathology, Westminster Hospital, for performing the laboratory investigations. I am very grateful to Professor C. E. Dent, University College Hospital for reading the manuscript and making many helpful suggestions.

\section{References}

Adams, P.H., Jowsey, J., Kelly, P.J., Riggs, B.L., Kinney, V.R. \& JONES, J.D. (1967) Effect of hyperthyroidism on bone and mineral metabolism in man. Quarterly Journal of Medicine, 36, 1.

Ahuja, M.M.S. \& Chopra, I.J. (1968) Co-existent hyperthyroidism and hyperparathyroidism. Metabolism, 17, 854.

Aub, J.C., Bauer, W., Heath, C. \& Ropes, M. (1929) Studies of calcium and phosphorus metabolism. III. The effects of thyroid hormone and thyroid disease. Journal of Clinical Investigation, 7, 97.

Aub, J.C., Albright, F., Bauer, W. \& Rossmeisl, E. (1932) Studies of calcium and phosphorus metabolism. VI. In hypoparathyroidism and chronic steatorrhoea with tetany, with special consideration of the therapeutic effect of thyroid. Journal of Clinical Investigation, 11, 211.

Austoni, M. (1965) Acute thyro-parathyrotoxicosis. Postgraduate Medical Journal, 41, 252.

BALL, R.G. (1930) Syndrome of hyperparathyroidism; report of a case. Proceedings of Staff Meetings of the Mayo Clinic, 5, 331.

Ballin, M. \& Morse, P.F. (1931) Parathyroidism. American Journal of Surgery, 12, 403.

BAXTER, J.D. \& BONDY, P.K. (1966) Hypercalcaemia of thyrotoxicosis. Annals of Internal Medicine, 65, 429.
Bergstrand, H. (1931) Ostitis fibrosa generalisata Recklinghausen mit pluriglandulärer Affektion der innersekretorischen Drüsen und röntgenologisch nachweisbaren Parathyroideatumor. Acta Medica Scandinavica, 76, 128.

Bowden, C.H. \& PAtston, V.J. (1963) Microdetermination of calcium and magnesium in biological materials. Journal of Clinical Pathology, 16, 18.

Bortz, W., Eisenberg, E., Bowers, C.Y. \& Pont, M. (1961) Differentiation between thyroid and parathyroid causes of hypercalcaemia. Annals of Internal Medicine, 54, 610.

Breuer, R.I. \& MCPherson, H.T. (1966) Hypercalcaemia in concurrent hyperthyroidism and hyperparathyroidism. Archives of Internal Medicine, 118, 310.

Bryant, L.R., Wulsin, J.G. \& Altemeier, W.A. (1964) Hyperparathyroidism and hyperthyroidism. Annals of Surgery, 159, 411.

Buckle, R.M., Mason, A.M.S., Middleton, J.E. (1969) Thyrotoxic hypercalcaemia treated with porcine calcitonin. Lancet, i, 1128.

CoOley, T.B. (1931) Hyperparathyroidism and similar diseases of bone. Transactions of the American Paediatric Society, 43, 20.

Cook, P.B., Nassim, J.R. \& Collins, J. (1959) The effects of thyrotoxicosis upon the metabolism of calcium phosphorus and nitrogen. Quarterly Journal of Medicine, 28, 505.

Cope, O. \& Donaldson, G.A. (1937) Relation of Thyroid and parathyroid glands to calcium and phosphorus metabolism. Study of a case with co-existent hypoparathyroidism and hyperthyroidism. Journal of Clinical Investigation, 16, 329.

David, N.J., Verner, J.V. \& Engel, F.L. (1962) Diagnositc spectrum of hypercalcaemia. American Journal of Medicine 33, 88.

Davies, D.R., Dent, C.E. \& Watson, L. (1968) Tertiary hyperparathyroidism. British Medical Journal, 3, 395.

DENT, C.E. (1956) Cortisone test for hyperparathyroidism. British Medical Journal, 1, 230.

DENT, C.E. (1962) Some problems of hyperparathyroidism. British Medical Journal, 2, 1419.

DENT, C.E. \& HARPER, C.M. (1958) Hypoparathyroid tetany (following thyroidectomy) apparently resistant to Vitamin D. Proceedings of the Royal Society of Medicine, 51, 489.

DENT, C.E. \& WATSON, L. (1966) Hyperparathyroidism and sarcoidosis. British Medical Journal, 1, 646.

EllenberG, A.H., Goldman, L., Gordon, G.S. \& Lindsay, S. (1962) Thyroid carcinoma in patients with hyperparathyroidism. Surgery, 51, 708.

Epstein, F.H., Freedman, L.R. \& Levitin, H. (1958) Hypercalcaemia, nephrocalcinosis, and reversible renal insufficiency associated with hyperthyroidism. New England Journal of Medicine, 258, 782.

FieLDS, M.L. \& BURKeTt, L.L. (1964) Multiple endocrine and metabolic disease syndrome. Journal of the American Medical Association, 188, 321.

Follis, R.H. (1953) Skeletal changes associated with hyperthyroidism. Johns Hopkins Hospital Bulletin, 92, 405.

Frame, B. \& Durham, R.H. (1959) Simultaneous hyperthyroidism and hyperparathyroidism. American Journal of Medicine, 27, 824.

Frizel, D., Malleson A. \& Marks V. (1967) Plasma levels of ionized calcium and magnesium in thyroid disease. Lancet, i, 1360.

GADEHOLT, H. (1961) Simultaneous hyperparathyroidism and Grave's disease. Acta Medica Scandinavica, 169, 283.

GaRCIA, D.A. \& YendT, E.R. (1968) Temporary remission of hypercalcaemia in hyperparathyroidism, induced by corticosteroids. Canadian Medical Association Journal, 99, 1047.

Gassman, R. \& HAAS, H.S. (1960) Akuter Hyperparathyroidismus. Schweizerische medizinische Wochenschrift, 90, 67. 
Gordan, G.S., Eisenberg, E., Loken, H.F., Gardner, B \& HAYASHIDA, T. (1962) Clinical endocrinology of parathyroid hormone excess. Recent progress in Hormone Research, 18, 297.

Gudmundsson, T.V., Galante, L,. Woodhouse, N.J.Y., MatTheWs, E.W., Osafor, T.D., MacINTYRe, I., KenNY, A.D. \& Wiggins, R.C. (1969) Plasma calcitonin in man. Lancet, i, 443.

GUYER, P.B. (1965) Hypercalcaemia in thyrotoxicosis. British Medical Journal, 1, 169.

GWINup, G. \& SAYle, B. (1961) Cortisone responsive hypercalcaemia in proved hyperparathyroidism. Annals of Internal Medicine, 55, 1001.

HARPER, P.S. \& OsBoRne Hughes, R. (1970) Severe hypercalcaemia from hyperthyroidism with unusual features. British Medical Journal, 1, 213.

Harris-Jones, J.N., Nakadar, A.S. \& Wells, A.L. (1967) Thyroid hormone and calcium metabolism. Lancet, i, 1328.

Harrison, M.T., Harden, R.M. \& Alexander, W.D. (1964) Some effects of parathyroid hormone in thyrotoxicosis. Jourral of Clinical Endocrinology and Metabolism, 24, 214.

Hellstrom, J. (1932) Hyperparathyroidism and ostitis fibrosa generalisata. Acta chirurgica Scandinavica, 69, 237.

Hellstrom, J. (1954) Primary hyperparathyroidism; observations in a series of 50 cases. Acta endocrinologica, 16, 30.

Hellstrom, J. \& Ivemark, B.I. (1962) Primary hyperparathyroidism. Acta chirurgica Scandinavica (Supplement), 294, 1.

Hodges, M. \& WATERHouse, C. (1967) Hypercalcaemia of hyperparathyroidism-responsive to Prednisone. Archives of Internal Medicine, 120, 75.

Hubble, D. (1958) Discussion on skeletal manifestations of general disease. Proceedings of the Royal Society of Medicine, 51, 475.

Huth, E.J., Maycock, R.L. \& KerR, R.M. (1959) Hyperthyroidism associated with renal tubular acidosis. American Journal of Medicine, 26, 818.

Jackson, C.E., Webster, J.S., Talbert, P.C. \& Caylor, H.D. (1961) Concomitant hyperparathyroidism as a cause of the hypercalcaemia associated with hyperthyroidism. Annals of Internal Medicine, 54, 992.

KeatiNG, F.R. JR (1961) Diagnosis of primary hyperparathyroidism. Journal of the American Medical Association, 178, 547.

Kleeman, C.R., Tuttle, S. \& Bassett, S.H. (1958) Metabolic observations in a case of thyrotoxicosis with hypercalcaemia. Journal of Clinical Endocrinology and Metabclism, 18, 477.

Klotz, H-P., Blahos, J., Delorme, M-L. \& Kanovitch, D. (1968) Les troubles du metabolisme calcique dans les affections thyroidiennes. Annales d'endocrinologie (Paris), 29, 624.

Koenig, M.P., Scholz, D.A., Salassa, R.M. (1957) Hypercalcaemia in hyperthyroidism. Review and report of 4 cases. Minnesota Mcdicine, 40, 782.
Krane, S.M., Brownell, G.L., Stanbury, J.B. \& CorriGAN, H. (1956) The effect of thyroid disease on calcium metabolism in man. Journal of Clinical Investigation, 35, 874.

LANCET (1967) Leading article. 1, 766.

LIM, P., JАCOB, E. \& K HOO, O.T. (1969) Handling of induced hypercalcaemia in hyperthyroidism. British Medical Journal, 4, 715.

Man, E.B., Gildea, E.F. \& Peters, J.P. (1940) Serum lipids and proteins in hyperthyroidism. Journal of Clinical Investigation, 19, 43.

MEYER-BORSTEL, H. (1930) Uber ostitis (osteo dystrophia fibrosa) Beiträge zur klinischen Chirurgie, 148, 436, 510.

Miller, E.S. \& Evans, L.R. (1942) Simultaneous hyperfunction of the thyroid and parathyroid glands. New England Journal of Medicine, 227, 949.

Noble, J.F. \& BoRg, J.F. (1936) Hyperparathyroidism complicated by hyperthyroidism. Report of a case. Archives of Internal Medicine, 58, 846.

Parsons, V. \& ANDERSON, J. (1964) The maximum renal tubular reabsorptive rate for inorganic phosphate in thyrotoxicosis. Clinical Science, 27, 313.

PribeK, R.A. \& MEADE, R.C. (1957) Thyrotoxicosis simulating hyperparathyroidism. Archives of Internal Medicine, $100,994$.

Puppel, I.D., Gross, H.T., McCormick, E.K. \& Herdle, E. (1945) The rationale of calcium, phosphorus and Vitamin D therapy in clinical hyperthyroidism. Surgery, Gynaecology and Obstetrics, 81, 243.

Randall, R.V. \& Keating, F.R. (1958) Serendipity in the diagnosis of primary hyperparathyroidism. American Journal of the Medical Sciences, 236, 575.

Rose, E. \& Boles, R.S. JR (1953) Hypercalcaemia in thyrctoxicosis. Medical Clinics of North America, 37, 1715.

SANDERSON, P.H. (1967) Renal potassium wasting in hypercalcaemia. British Medical Journal, 1, 679.

Sataline, L.R., Powell, C., Hamwi, G.J. (1962) Suppression of the hypercalcaemia of thyrotoxicosis by corticosteroids. New England Journal of Medicine, 267, 646.

Stanley, M.M. \& FazeKas, J. (1949) Thyrotoxicosis simulating hyperparathyroidism. American Journal of Medicine, $7,262$.

ToRSTI, P. \& LAmberg, B-A. (1963) Co-existing hyperthyroidism and hyperparathyroidism. Acta Medica Scandinavica, 174, 115.

Von Recklinghausen, F.C. (1891) Die fibrose oder deforminende ostitis, die osteomalacie und die osteoplastische carcinose in ihren gegenscitigen Bezichungen. In Festschrift Rudolf Virchow, p. 20. Reemer. Berlin.

Wendel, W. (1930) Zur ostitis fibrosa generalisata. Deutsche Zeitschrift für Chirurgie, 227, 551.

WERnER, S.C. (1962) The Thyroid. 2nd Ed. P. 628. Harper and Row, New York.

WiJnbladH, H.J. (1937) Uber die Thyreotoxischen Krisen und ihre Behandlung mit Besonderer Berucksichtigung der Jodbehandlung. Acta Chirurgica Scandinavica, 79, 507.

\section{Addendum}

Since the submission of this paper, the following has been published:

Parfitt, A.M. \& Dent, C.E. (1970) Hyperparathyroidism and hypercalcaemia. Quarterly Journal of Medicine, 39, 171. 